\title{
RAZVOJ GEOGRAFSKIH KURIKULOV IN IZOBRAŽEVALNI POTENCIAL GEOGRAFIJE NA ZAČETKU 2I. STOLETJA
}

\author{
Karmen Kolenc Kolnik \\ Oddelek za geografijo Filozofske fakultete Univerze v Mariboru, \\ Koroška cesta 160, SI - 2000 Maribor, Slovenija \\ e-mail: karmen.kolenc@uni-mb.si
}

Izvirni znanstveni članek

COBISS 1.01

\section{Izvleček}

V primerjalni analizi so razčlenjene nekatere značilnosti razvoja geografskih kurikulov izbranih držav v zadnjih dvajsetih letih tako, da je bila zasledovana njihova aplikativna naravnanost na vedno nove družbene in izobraževalne potrebe. Osnovno raziskovalno vprašanje je bilo usmerjeno v iskanje odgovora na katere vrste znanj in veščin naj bi (oz. je) vzpodbujalo geografsko izobraževanje v okviru geografskih izobraževalnih smernic in s kakšnimi učnimi pristopi bodo (so) le-te realizirali?

Ključne besede: geografija, razvoj kurikula, izobraževalni potencial

\section{DEVELOPMENT OF GEOGRAPHICAL CURRICULA AND THE EDUCATIONAL POTENTIAL OF GEOGRAPHY AT THE BEGINNING OF 2 I $^{\text {st }}$ CENTURY}

\begin{abstract}
The comparative analysis introduces some characteristics of the development of geography curricula of chosen countries and ascertains the applicative direction of school curricula toward the new social and educational needs. The author discusses the knowledge and abilities that should be (or have been) stimulated by geographical education within the framework of geographical educational tendencies and teaching approaches which are needed for their realization.
\end{abstract}

Key words: geography, development of the curricula, educational potential 


\section{UVOD}

Značilnosti sodobne družbe ne moremo pojmovati kot statično in preprosto opisljivo stanje, temveč kot vrsto medsebojno povezanih in prepletenih premikov: socialnih, ekonomskih, okoljevarstvenih, demografskih, zgodovinskih, političnih, ... pa tudi geografskih. Vprašanje uspešnosti odziva šolske sfere nanje je treba razumeti kot razvojni izziv, izobraževalni sistem pa kot enega od osrednjih podsistemov, ki morajo spremljati spremembe. Velike družbeno politične spremembe v Evropi, hiter tehnološki razvoj, izčrpavanje naravnih virov, demografski pritiski, katastrofalne napake pri posegih v prostor, so le nekatere od družbenih značilnosti konca 20. stoletja. Odločilni impulzi za reforme na področju šolstva so v sredini osemdesetih let 20. stoletja izhajali iz gospodarskih in socialno-kulturnih sprememb v gospodarsko najmočnejših državah in širjenju vplivov globalizacije, kar je pomenilo intenziven prodor na nove trge in spremenjene oblike medsebojnega povezovanja in življenja. Vedno pomembnejši je postajal vsak posameznik, na katerega je država zopet prenesla večjo odgovornost. Okrepil se je privatni in gospodarski sektor na račun javnega in političnega. Gospodarska konkurenčnost in migracije delovne sile so izpostavili nacionalne šolske sisteme nenehni mednarodni konkurenci in ni naključje, da PISA-študije o izobraževalnih učinkih spadajo pod okrilje OECD (Organisation for Economic Cooperation and Development - Organizacija za gospodarsko sodelovanje in razvoj). Tako so bile države prisiljene k reformam v šolstvu, saj si tako zagotavljajo konkurenčnost na svetovnem trgu. Spreminjajo se kurikuli, pa ne le z novimi, posodobljenimi učnimi vsebinami temveč tudi z uvajanjem standardov znanja in standardiziranih nacionalnih preverjanj znanj, ki jih lahko morda primerjamo z v gospodarstvu poznano kontrolo kvalitete in standardov kakovosti.

Vedno več je govora o učenčevih kompetencah (Löwisc 2000, Resnik Planinc, Kosten Zabret 2007), še posebej o kroskurikularnih kompetencah in kompetenci odločanja in odgovornosti vsakega posameznika. Izobraževanje mora posredovati znanja in vsakemu posamezniku pomagati, da si pridobi orientacijsko znanje in ključne sposobnosti, tako da bo lahko v prihodnosti prevzel več odgovornosti zase in okolje, v katerem živi. »Globalno učenje« vsebuje prizadevanja posredovati interdisciplinarni vidik pomembnih vprašanj civilizacije, kot so odnosi med severom in jugom, multikulturnost, mir, človekove pravice, omejeni naravni viri, itd.. (Schallhorn 2004, Marentič Požarnik 2005) Izobraževalna usmeritev je zahteva po kompetencah, ki nam bodo omogočale, da se bomo znašli v kompleksnem svetu, bili sposobni sprejeti odgovornost, in na ta način postali zmožni preživeti v prihodnosti. Pri tem ima geografija pomembno vlogo, saj je že v svoji zasnovi interdisciplinarna veda, ki združuje znanja veliko področij.

Izobraževanje postaja $\mathrm{v}$ zadnjih letih prednostna naloga $\mathrm{v}$ večini držav članic Evropske unije. Vendar se velika inflacija pričakovanj in nalog, ki se postavljajo tako pred celoten izobraževalni sistem, kot pred posamezne šolske predmete in učitelje ( tudi pred učitelje geografije), ne ujemajo z nujno potrebno finančno in sistemsko podporo ( Kolenc Kolnik, 2005), ki je ob inovativnih kurikulih tudi predpogoj, da teorija (družbena pričakovanja, želje, potrebe,...) preide $\mathrm{v}$ izobraževalno in nato življenjsko prakso mladih. 


\section{DRUŽBENE POTREBE IN IZOBRAŽEVALNI POTENCIAL GEOGRAFIJE OB PRELOMU TISOČLETJA}

Pri analiziranju razvojnih usmeritev geografskega izobraževanja (v ožjem smislu šolske geografije), ne moremo mimo razvoja geografije kot znanstvene panoge in njenih odzivov na družbene potrebe na eni strani in interdisciplinarne zasnove didaktike geografije (in nanjo vezane šolske geografije) na drugi strani, saj so med seboj součinkojoče povezani. Historiat njihovega dosedanjega povezovanja nam lahko pomaga opredeliti, kako so jih zaznali in $\mathrm{v}$ učne načrte predmeta umestili sestavljavci geografskih kurikulov.

Slika 1 : Izobraževalne tendence v geografskih kurikulih druge polovice 20.stoletja Picture 1: Educational tendencies of geographical curriculums in the late 20.century

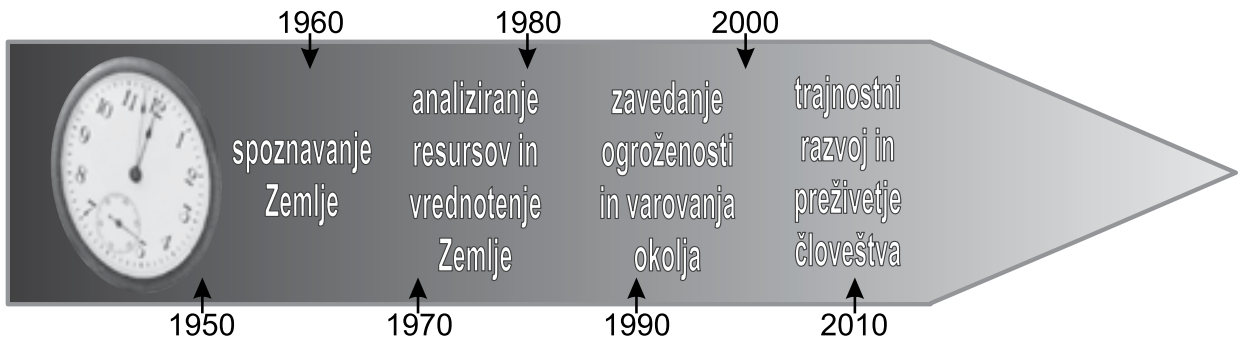

Vir: prirejeno po Kolenc Kolnik, Resnik Planinc $2006 a$

Pregled razvojnih usmeritve geografskega izobraževanja v drugi polovici 20. stoletja v slovenskem in evropskem prostoru pokaže ( Kolenc Kolnik, Resnik Planinc 2006a), da je bilo v šestdesetih in sedemdesetih letih prejšnjega stoletja, z geografsko izobraževalnega vidika na Zemljo gledano kot na prostor naravne in družbene raznolikosti in prostor nasprotij. $\mathrm{V} 70$-ih in 80-ih je bila Zemlja $\mathrm{v}$ šolski geografiji pojmovana kot prostor načrtovanja raznolikih namembnosti in uporabnosti. Zadnje desetletje minulega stoletja prinese zavedanje, da je potrebno vzpostaviti kvalitetnejše odnose v rabi prostora: popraviti odnos do okolja, soljudi in prihodnjih rodov (vzgoja za sožitje, multikulturna vzgoja, okoljska vzgoja). Začetek 21 . stoletja tesno poveže šolsko geografijo z interdisciplinarnim učnim ciljem varovanja okolja s preživetjem človeštva in trajnostnim razvojem na lokalnem, regionalnem in planetarnem nivoju.

Pri vseh ugotovljenih razvojnih spremembah je zaznati, da se sestavljavci geografskih kurikulumov v Evropi (pa tudi širše) različno hitro in različno intenzivno odzivajo na širše družbene in geografske spremembe, kot tudi same izobraževalne potrebe.

\section{GEOGRAFSKI KURIKULI OB KONCU 20. STOLETJA}

Leta 1988 so v Veliki Britaniji sprejeli obsežno šolsko reformo (Greta Education Reform Bill) in leto kasneje še obvezni National Curriculum (Petek 2003), ki je vključeval 
izobraževalne standarde in kontrolo kvalitete. Kurikul so sestavljali trije temeljni predmeti (angl. Core subject): angleščina, matematika in naravoslovje ter sedem osnovnih predmetov (angl. Foundation subjects), kamor je bila uvrščena tudi geografija. Primarno izobraževanje so sestavljala štiri šolska obdobja. V prvih treh šolskih obdobjih (angl. Key Stages 2, 3-6,7-9) je bila geografija obvezna, v četrtem obdobju ( angl. Key stage 10-11) pa je bila umeščena med izbirne predmete (Schallhorn 2004). Prevladujoči delež učnih ciljev in vsebin je bil namenjen spoznavanju lastne domovine, še posebej na lokalnem nivoju, z izrazito težnjo po vpeljevanju izkustvenega učenja (angl. Learning by doing). To je tudi obdobje, ko se v učnem načrtu za geografijo trdno umesti učenje na prostem (angl. Outdoor Learning) in terensko delo (angl. Field work), ki postaneta v naslednjem desetletju težišče načrtovane dejavnosti učencev ( Foskett 2000, Kestler 2002).

V ZDA so devetdesetih letih prejšnjega stoletja ponovno odkrili izobraževalni pomen geografije: „Rediscovering Geography - New Relevance for Science and Society” je bil naslov poročila, ki ga je leta 1997 objavil National Academy Press (Scholbrun 2004). Pri ponovno prepoznavnem izobraževalnem potencialu geografije so pomembno vlogo odigrali globalizacija, globalni sindromi ogroženosti okoljskih sistemov in principi trajnega razvoja, pa tudi vedno večja »politično-geografska nepismenost » državljanov ZDA. Izobraževalni potencial in osnovni cilj geografije je bil opredeljen s potrebo usposobiti mlade za uspešen spopad z izzivi 21. stoletja. Zanje naj bi učenci razvijali kompetentnosti s področij, ki omogočajo razvijanje sposobnosti uspešnega vključevanja v svetovno konkurenco in vpogled $\mathrm{v}$ povezave med gospodarskim razvojem, zagotavljanjem resursov in varovanjem okolja. V izboru učnih vsebin je bilo moč zaslediti elemente prepletanja regionalistične paradigme (odnosi človek - prostor) in elemente prostorske paradigme ( prostor in njegova lokacija, struktura prostorov in procesi v prostorskih enotah), ki so bili opredeljeni v petih temeljnih točkah. Učno ciljna in vsebinska izhodišča so bila razvojno naravnana, vendar nikoli podkrepljena $\mathrm{z}$ ustrezno izobraženimi učitelji in predmetnimi kurikuli. V ameriški šolski geografiji jih je Nash označil kot zamujeno priložnost, so pa imela vpliv na razvoj npr. angleških, nemških in japonskih geografskih kurikulov (Scholbrun 2004, Haubrich 2005). V Sloveniji se v letu 1990 prične prenova geografskih učnih načrtov tudi zato, ker Slovenija postane samostojna država. Prvič se sestavijo katalogi izobraževalno- vzgojnih ciljev pouka geografije za osnovno šolo in različne stopnje srednjih šol. Vanje je bila vključena izbira in razporeditev učnih vsebin glede na vodilni cilj (eksemplarni izbor držav, prostorskih procesov, učnih nalog, ipd.). Nova izhodišča za oblikovanje kurikula so bila posledica, tako hitro razvijajočih se smeri v geografski znanosti in njihovih spoznanj (npr. socialna geografija, politična geografija,...), kot tudi novih smernic na pedagoško- didaktičnem znanstvenem področju (raziskovanje kurikuluma, pomen učnih ciljev, taksonimije učnih ciljev, itd.) in v celotni družbi (Birkenhauer 1999, Kunaver 1999).

Namenski vidik pouka geografije je ostal nespremenjen; še vedno je to splošno izobraževalni predmet za osnovno in srednje šole. Vrednostni vidik načrtovanja pouka geografije je temeljil na opredelitvi geografije kot kompleksne in problemske vede. Temeljni namen predmeta je bil zelo širok in je učence usmerjal v razumevanje sveta, dojemanje dinamičnega součinkovanja elementov, ki ga sestavljajo, ter v spoznanju neprestanega razvoja in preob- 
likovanja prostora. Snovno-vsebinski vidik načrtovanja pouka geografije je zajemal izbor učnih vsebin, ki so ohranjale delitev na obče geografske in regionalno geografske vsebine. Sočasno pa je njihov velik vsebinski obseg doživljal nenehne kritike s strani učiteljev, pa tudi učencev in staršev. Pomembnejši premiki so bili zaznani pri vpeljevanju aktivnejših učnih metod, kot je izkustveno podprto učenje geografije na prostem. Šolske ekskurzije in terensko delo se predelijo kot obvezni del kurikula (Kolenc-Kolnik 2005).

\section{RAZISKAVA: IZOBRAŽEVALNE TENDENCE V OSNOVNOŠOLSKIH KURIKULIH IZBRANIH DRŽAV}

V letu 2006 in 2007 so se v Sloveniji odvijale številne strokovne razprave o položaju geografije v izobraževalnem kurikulu, zlasti v luči napovedane prenove gimnazijskega programa in prenov predmetnih kurikulov (učnih načrtov). V želji po ugotovitvi »ustrezne naravnanosti« pouka geografije z opredeljenimi razvojnimi dejavniki in izobraževalnimi izzivi, so bile tudi objavljene različne analize ciljev prenove in izobraževalno vzgojnih ciljev pouka geografije (Kolenc Kolnik, Resnik Planinc 2006a, 2006b; Resnik Planinc, Kosten Zabret 2007). Ugotovljeno je bilo, da bi v šolski geografiji morali. »... težiti k odmiku od k poučevanju usmerjenega učnega načrta ( $\mathrm{k}$ učiteljevem delu usmerjenega učnega načrta) ter se v večji meri osredotočiti na rezultate učenčevega učenja (v učenje oz. učence usmerjenega učnega dela). K individualizaciji in personalizaciji kurikula in intenzivnemu razvijanju zahtevnejših kroskurikularnih veščin, kot so na primer reševanje problemov, besedno in nebesedno sporazumevanje, kritično mišljenje, ustvarjalnost ter k uporabi informacijsko komunikacijske tehnologije« (Kolenc Kolnik, Resnik Planinc 2006b, 9). Namen raziskave je bil proučiti kakšno mesto ima geografija v sodobnih osnovnošolskih kurikulih Velike Britanije (Anglije), Avstrije, Hrvaške in Slovenije, ter na katerem od možnih geografskih pristopov pri proučevanju prostora/oz.pokrajin temeljijo izbrani kurikuli osnovnošolskega izobraževanja. Pri tem smo želeli zlasti ugotoviti, v kolikšni meri so smernice in temeljna načela načrtovanja kurikulumov v Sloveniji primerljive z izobraževalnim potencialom geografije in geografskimi učnimi načrti izbranih držav.

Vzrok za izbor kurikulov na osnovnošolskih stopnji je bil v dejstvu, da je geografija prevladujoče zastopana kot šolski predmet prav na tej stopnji izobraževanja in bistveno manj na sekundarni stopnji, sočasno pa so izobraževalni sistemi v Evropi tudi notranje primerljivejši na primarni stopnji izobraževanja. Izhodišče raziskovanja je temeljilo na hipotezi, da izbrani geografski učni načrti sledijo tako nacionalnim izobraževalnim smernicam, kot tudi aplikativnim posebnostim geografskega izobraževanja. Slednje se kažejo predvsem v potrebi, da se učenje o prostoru izvajna v izkustveni obliki učenja v prostoru (npr. terensko delo).Osnovni raziskovalni metodi sta deskriptivna in kavzalno - neksperimentalna. Na osnovi deskriptivne analize strokovne literature o proučevanem pojavu, smo v empiričnem delu raziskovanja zbirali podatke s pomočjo analize pedagoške dokumentacije ter izbranih učnih načrtov pouka geografije v osnovni šoli. Podatki, ki so pridobljeni z analizo so predstavljeni tabelarično ter interpretirani na kavzalnem nivoju. 


\section{I Ugotovitve s komentarjem}

Primerjava geografskih kurikulov Slovenije, Anglije, Avstrije in Hrvaške pokaže, da so vse države v svoje predmetne kurikule (učne načrte) vključile tako regionalistično kot prostorsko paradigmo. Angleška in avstrijska osnovnošolska (delno tudi srednješolska) geografska kurikuluma dajeta prednost izbranim geografskim temam in proučevanju odnosa med človekom in naravo na izbranih učnih vsebinah. Drugačen pristop v koncipiranju imata slovenski in hrvaški kurikul, ki sta medsebojno (še vedno) najbolj primerljiva, tako v vsebinski regionalni strukturi (izbor lokalnih, nacionalnih in globalnih regij) kot $\mathrm{v}$ opredeljenih dejavnostih učencev in časovnem obsegu.

V Veliki Britaniji (Angliji) so prenovili The National Curriculum (2000) v katerem je geografija še vedno opredeljena kot obvezni učni predmet $\mathrm{v}$ prvih treh izobraževalnih obdobjih. Novost je, da so od leta 2000 dalje lahko šole same razvijale kurikulum za izbirne predmete. To je bil odgovor na kritične pripombe, da niso bile ustrezno upoštevane specifične razlike med učenci, ter da ni bila ciljno vključena kreativnost učencev. V geografskem kurikulu za prva tri izobraževalna obdobja je bilo začrtano pet temeljnih ciljev: razumevanje geografskih vsebin, geografsko raziskovanje in razvoj veščin, poznavanje in razumevanje prostora, razumevanje prostorskih vzorcev in procesov in razumevanje okoljskih sprememb in trajnostnega razvoja. Vsebinski del kurikula omogoča izbirnost in določa minimalni obseg, to sta dve poljubno izbrani angleški pokrajini in tri geografske teme (npr. voda in njen vpliv na pokrajino, transformacija naselij, okoljski problemi, itd.). Učne dejavnosti učencev so usmerjene $\mathrm{v}$ usposabljanje le-teh za reševanje okoljskih problemov in problemov z vidika trajnostnega razvoja. Učenje na prostem, kot izkustvena oblika učenja, je osnova in je opredeljeno kot učna dejavnost za pridobivanje geografskih informacij o prostoru. Skoraj polovica učnega dela se naj bi izvajala izven šolskih učilnic (Foskett 2000). V zadnjem, četrtem izobraževalnem obdobju ima geografija status izbirnega predmeta. Vendar pa so v spremljajočih kurikularnih evalvacijah ugotovljali (Bell 2005), da ni vedno dobro v celoti prepustiti kurikul izbirnih predmetov šolam oz.učiteljem, saj le-ti hitreje podležejo pritiskom (npr.dokazovanja uspešnosti na nacionalnih preizkusih znanj) in pri izbirnih predmetih vso pozornost usmerijo v pripravo na zaključne preizkuse znanj ter močno povečajo število geografskih vsebin (informacij ) na račun aktivnih metod učenja (terensko delo). Bell tako ugotavlja (2005), da sta priljubljenost geografije in zanimanja učencev za ta izbirni predmet $\mathrm{v} 10$ in 11 razredu $\mathrm{v}$ zadnjih 8 letih upadla kar za tretjino učencev. To pripisuje zmanjševanju deleža terenskega dela in z njim povezane usmerjenosti $v$ izkustveno učenje in učenje reševanja lokalnih problemov. Zadovoljstvo učencev s predmetom povezuje tudi $z$ njihovim učnim uspehom, ki je višji v prvih treh izobraževalnih obdobjih, kjer je v obvezni predmet geografija vključeno veliko izkustvenega učenja (usmerjevalni kurikul). Pretirana orientacija na preverjanja znanja ne dopušča odprtosti in kreativnosti pri pouku, manj se lahko upoštevajo posebne potrebe in interesi učencev (Westaway in Rawling 2001).

V Avstriji se pouk geografije prične v Hauptschule (časovno delno primerljivo s tretjo triado naše osnovne šole). Hauptschule je razdeljena na štiri razrede in njena naloge je učencem posredovati splošno znanje. Na tej stopnji pripravljajo tudi učence na odločitev za poklicno pot in s tem nadaljnje šolanje. Težišče je na povezovanju prakse in teorije ter 
Preglednica 1: Učne vsebine v geografskem kurikulu (osnovna šola): Anglija, Avstrija, Hrvaška, Slovenija

Table 1: Teaching contents in the geographical curricula (primary school): England, Austria, Croatia and Slovenia

\begin{tabular}{|c|c|c|c|c|c|}
\hline Država & \multicolumn{5}{|c|}{ Razred in učna vsebina } \\
\hline $\begin{array}{l}\text { Anglija } \\
\text { Key stage } \\
2 \text { in } 3^{*}\end{array}$ & $\begin{array}{l}\text { Year } 6 \\
\text { Raziskovanje rek; } \\
\text { Gorsko okolje; } \\
\text { Aktualne teme pri } \\
\text { poročilih }\end{array}$ & \multicolumn{2}{|c|}{$\begin{array}{l}\text { Year } 7 \\
\text { Rraziskovanje } \\
\text { Anglije; } \\
\text { Iskanje povezav; } \\
\text { Katastrofalne } \\
\text { poplave - kako } \\
\text { ukrepati? Vse- } \\
\text { povsod ljudje; } \\
\text { Svetovni športi; } \\
\text { Vstopnica v svet; }\end{array}$} & $\begin{array}{l}\text { Year } 8 \\
\text { Obalna območja; } \\
\text { Vremenski vzorci } \\
\text { v Evropi; Razis- } \\
\text { kovanje Brazilije, } \\
\text { Kako Zemlja } \\
\text { zmore? ekosiste- } \\
\text { mi, populacija, } \\
\text { naravni viri; } \\
\text { Nakupovanje : } \\
\text { nekoč-danes-jutri; } \\
\text { Vstopnica v svet }\end{array}$ & $\begin{array}{l}\text { Year } 9 \\
\text { Kaj je razvoj? } \\
\text { spreminjanje } \\
\text { ekonomske geo- } \\
\text { grafije Francije, } \\
\text { svetovna modna } \\
\text { trgovina; Virtu- } \\
\text { alni vulkani in } \\
\text { internetni potresi; } \\
\text { Lokalno ukrepanje } \\
\text { in globalni efekti; } \\
\text { Vstopnica v svet }\end{array}$ \\
\hline $\begin{array}{l}\text { Avstrija } \\
\text { Hauptschule** } \\
\text { (Geographie und } \\
\text { Wirtschaftkunde) }\end{array}$ & \multicolumn{2}{|c|}{$\begin{array}{l}2 \text {. Klasse } \\
\text { Življenje v urbanih aglomeracijah; } \\
\text { Proizvodnja dobrin v obrtnih in } \\
\text { industrijskih obratih; } \\
\text { Terciarni sektor oz. storitvene } \\
\text { dejavnosti; } \\
\text { Zemlja kot življenjski in gospodar- } \\
\text { ski prostor }\end{array}$} & \multicolumn{2}{|c|}{$\begin{array}{l}\text { 3. Klasse } \\
\text { Avstrija; } \\
\text { Človekovo oblikovanje } \\
\text { življenjskega prostora; } \\
\text { Vpogled v svet dela, } \\
\text { privatna gospodinjstva, } \\
\text { gospodarska povezava } \\
\text { Avstrije z Evropo }\end{array}$} & $\begin{array}{l}\text { 4. Klasse } \\
\text { Skupna in razno- } \\
\text { lika Evropa; Centri } \\
\text { in obrobja v gospo- } \\
\text { darstvu; } \\
\text { Življenje v razno- } \\
\text { likem svetu; } \\
\text { Globalizacija }\end{array}$ \\
\hline Hrvaška & $\begin{array}{l}\text { 5. razred } \\
\text { Zemlja kot celota }\end{array}$ & \multicolumn{2}{|c|}{$\begin{array}{l}\text { 6. razred } \\
\text { Prebivalstvo } \\
\text { sveta; Regionalna } \\
\text { geografija sveta }\end{array}$} & $\begin{array}{l}\text { 7. razred } \\
\text { Evropa }\end{array}$ & $\begin{array}{l}\text { 8. razred } \\
\text { Hrvaška } \\
\text {-domovina }\end{array}$ \\
\hline Slovenija & $\begin{array}{l}\text { 6. razred } \\
\text { Zemlja kot celota }\end{array}$ & \multicolumn{2}{|c|}{$\begin{array}{l}\text { 7. razred } \\
\text { Geografske } \\
\text { značilnosti Ev- } \\
\text { rope in Azije }\end{array}$} & $\begin{array}{l}\text { 8. razred } \\
\text { Geografske } \\
\text { značilnosti } \\
\text { Amerike, Afrike, } \\
\text { Avstralije in po- } \\
\text { larnih območij }\end{array}$ & $\begin{array}{l}\text { 9.razred } \\
\text { Slovenija, } \\
\text { naša domov- } \\
\text { ina }\end{array}$ \\
\hline
\end{tabular}

Vir: The National Curriculum attainment targets, stage $1 \& 2 \& 3$, Medmrežje 7;

Hauptschule, Medmrežje 3; Nacionalni izobraževalni standard 2005, Medmrežje 6;

Učni načrt:program osnovnošolskega izobraževanja. geografija. Predmetna kurikularna

komisija za geografijo. ZRSŠ. 2001

Opomba: "primerljivo s predmetno stopnjo v Sloveniji

"* primerljivo s tretjo triado devetletne osnovne šole v Sloveniji

približevanju resničnih življenjskih situacij učencem. Predmet geografija se pojavlja pod imenom Geographie und Wirtschaftskunde (Geografija in gospodarstvo) in je na urniku po dve uri tedensko $v$ vseh štirih razredih. Temeljno izobraževalno poslanstvo je opredeljeno kot 
usposablje učencev za odgovorno in tolerantno delovanje v zasebnem, poklicnem in javnem življenju. Učne vsebine so vezane na prostorske učinke človekovega delovanja na primeru gospodarstva, pri tem je pomembna časovna komponenta in možnosti medpredmetnih povezovanj. Izbrane učne teme se konkretizirajo na različnih tipih regij, ni sistematičnega regionalno geografskega proučevanja. V izboru učnih dejavnosti je poudarek na usposabljanju za uporabo različnih geografskih metod dela in razvijanju veščin in sposobnosti s področja samoizobraževanja (Medmrežje 3, 5).

Hrvaška ima s Slovenijo najbolj primerljivo sestavo geografskega kurikula. Geografija oz. zemljopis je samostojen šolski predmet od petega do osmega razreda v osemletni osnovni šoli. Nacionalni izobraževalni standard (NOS) opredeljuje obseg znanja s t.i.kataloškimi učnimi temami in ključnimi pojmi, ki jih je potrebno usvojiti. V enem šolskem letu je tako v 70 urah potrebno načrtovati največ 20 obveznih in 5 izbirnih kataloških tem. Izbirne kataloške teme vzpodbujajo aktualizacijo učnih vsebin.Učne dejavnosti učencev so močno usmerjene v izkustveno učenje, usposabljanje za timsko delo na terenu in aktivno bivanje v naravi in jih opredeljuje kot osnovne izobraževalne smernice. Tako je geografsko terensko delo v 5. razredu predvideno pri devetih obveznih in dveh izbirnih temah (npr. obisk zvezdarne, orientacija na prostem, kartiranje smetišč) v 6. razredu pri eni obvezni učni temi (obisk etnografskega muzeja), v 7. razredu terensko delo ni predvideno, v 8. razredu je predvideno pri šestih obveznih vsebinah in petih izbirnih vsebinah (npr. državni mejni prehod, meteorološka postaja, naravni ali nacionalni park, pristanišče, poljedeljski sejem). Kot pomembno izobraževalno usmeritev definirajo tudi medpredmetne povezave, ki so podrobno razčlenjene pri vsakem vsebinskem sklopu.

V srednješolskih programih geografija ohranja pomembno mesto v splošno izobraževalnih gimnazijskih programih. Tudi tu, enako kot v osnovno šolskem kurikulu, ohranjajo regionalno geografski pristop, z izrazitim primerjavami »Hrvatska i svet«, ki v učnih ciljih in učnih vsebinah nosijo močan identifikacijski in domoljuben naboj (Medmrežje 6).

V Sloveniji se začenja sredi devetdesetih let prenova osnovnošolskega izobraževanja s postopnim uvajanjem devetletne osnovne šole. Med spremljajoče pozitivne premike na področju šolske geografije v tem obdobju lahko uvrstimo razvoj didaktične opreme in ponudbe strokovnih spolnjevanj za učitelje.

V strukturi osnovnošolskega kurikula smo pridobili 35 učnih ur v 6. razredu, ki so namenjene obče geografskim vsebinam. Geografija je v osnovnošolsko izobraževanje vključena tudi z izbirnima predmetoma Življenje človeka na Zemlji in izbirni predmet Razisko-vanje domačega kraja ter varstvo njegovega okolja. Med temeljna načela prenove geografskih učnih načrtov se $\mathrm{v}$ tej prenovi uvrščata učno ciljni pristop in večjo usmerjenost $\mathrm{k}$ potrebam učencev (njihovi zaznavni in doživljajski raznolikosti) in delno k izkustvenemu učenju ( živimo v prostoru). Ohranja se regionalno geografski izbor učnih vsebin. Med pozitivne premike v načrtovanih dejavnostih učencev uvrščamo vsakoletno obvezno interdisciplinarno ekskurzijo in obvezni dve krajši obliki terenskega dela. Pomembna novost je tudi priporočen procesno-razvojni pristop v izboru učnih vsebin in metod dela.

V začetku 2007 se je pričela prenova vseh osnovnošolskih in srednješolskih učnih načrtov in naj bi se zaključila v letu 2008. 


\section{SKLEP}

Stalno spremljanje, posodabljanje in razvoj kurikula ostajajo del šolskega sistema, saj izobraževanje izhaja iz družbenih potreb in se mora odzivati na usmeritve sodobne družbe, v kateri imajo velik pomen znanje in njegovi učinki. Kurikulum mora poudarjati razvijanje tistih zmožnosti posameznika, ki vodijo k sposobnostim za stalno učenje.

$\mathrm{Ob}$ intenzivnih spremembah, tako nacionalnih kot predmetnih kurikulov, ne smemo pozabiti, da bodo le-ti, četudi še tako inovativno naravnani, uspešno realizirani le, če bodo v šolah poučevali strokovno ter profesionalno suvereni in avtonomni učitelji.

V sodobnih evropskih geografskih kurikulumih je geografija definirana kot šolski predmet, ki medpredmetno izobražuje in vzgaja tako z naravoslovnimi kot družboslovnimi vsebinami.

Primerjava geografskih kurikulov izbranih držav kaže, da so Slovenija, Anglija, Avstrija in Hrvaška kot izhodišče geografskega proučevanja vključile tako regionalistično kot prostorsko paradigmo. Angleška in avstrijska osnovnošolska (delno tudi srednješolska) geografska kurikuluma dajeta prednost izbranim geografskim temam in proučevanju odnosa med človekom in naravo. Drugačen pristop v koncepiranju imata slovenska in hravaška kurikula, ki sta medsebojno še vedno najbolj primerljiva, tako v vsebinski strukturi, opredeljenih dejavnostih učencev in časovnem obsegu.

V prihodnosti je pričakovati, da bodo: prostor, njegova lokacija in razporeditev, odnos med človekom in okoljem oz. prostorske interakcija ostali temeljni postulati geografskega izobraževanja, ker vzpodbujajo z učenjem o prostoru tudi razvijanje participatornega in proaktivnega učenja kot pomembnih elementov v trajnostni razvoj usmerjenega izobraževanja. Pomembno je spoznanje, da geografska izobrazba lahko pomembno prispeva k posameznikovem poznavanju, razumevanju in vrednotenju lokalnega in nacionalnega prostora in njihovo soodvisno povezanostjo s svetom. Poučevanje geografije naj bo orientirano v razumevanje vrednot, odnosov in načinov rabe prostora povezanih $\mathrm{z}$ načeli trajnostnega razvoja. Učenje o problemih sodobnega sveta omogoča učencem prepoznati in ozavestiti njihove obveznosti in pravice, zato naj bi vsi učenci imeli možnost in znanje, da razvijajo družbeno (socialno, politično, ekološko,...) ozaveščenost in odgovornost v odločanju o skupnih problemih ter v iskanju uravnoteženega razvoja tako med posameznikovimi in družbenimi interesi kot med interesi družbe in zaščite narave.

\section{Literatura in viri}

Bell, D., 2005. The value and importance of geography. Teaching geography, Vol.30. No.1. Sheffild, str. 12-13.

Birkenhauer, J., 1999. Vaterländische und Völkische Erdkunde. Education for Sustainable Developmnt, 2005. Good Practice Guide for Primary, Secondary and special Schools, Interboard Education for Sustainable Development Group. Curriculum Advisory \& Support Service. Northern Ireland.

Foskett, N.2000. Fieldwork and developement of thinking skills. Teaching Geography, Vol. 25, No.3. Sheffild, str. 17-20. 
Haubrich, H.2005. Učenje geografije za prihodnost, V: Kunaver (urednik) Slovenska šolska geografija s pogledom v prihodnost. DZS. Ljubljana, str.13-18.

Kestler, F.2000. Einführung in die Didaktik des geographieunterricht, Klinkhardt, Bad Heilbrum.

Kolenc-Kolnik, K. 2005. Učenje za odgovorno prihodnost: primer učenja za kompetentno ravnanje s prostorom. Didactica Slovenica., Pedagoška obzorja, št. 3-4. Novo mesto, str. 58-67.

Kolenc-Kolnik, K., Resnik Planinc T., 2006a. Izobraževalno poslanstvo geografije. Šolsko polje, letnik. 17, št. 5/6. Ljubljana, str. 71-82.

Kolenc-Kolnik, K., Resnik Planinc T., 2006b. Izzivi prenove gimnazijskega programa z vidika geografskega izobraževanja. Geografski obzornik, letnik 53, št. 4. Ljubljana, str. 48-56.

Kunaver, J. 1999. Slovenska šolska geografija na prelomu stoletja. Dela. Št. 14. Oddelek za geografijo Filozofske fakultete Univerze v Ljubljani. Ljubljana, str.77-90.

Löwisc, D.J., 2000. Kompetents handeln: bausteine für eine lebensweltbezogene Bildung Wisseenchaftiche Buchgeseltschaft. Darmstadt.

Marentič-Požarnik, B.2005. Vpetost v sodobna pojmovanja učenja in pouka - nujnost in hkrati izziv za geografsko izobraževanje, V: Kunaver (urednik) Slovenska šolska geografija s pogledom v prihodnost, DZS. Ljubljana, str.19-23.

Petek, J. 2003. Poučevanje geografije v Angliji. Sklepna seminarska naloga, Pedagoška fakulteta Univerze v Mariboru. Maribor.

Resnik Planinc, T. 2005. Didaktična analiza geografskih učnih vsebin v slovenski šolski geografiji. Slovenska šolska geografija s pogledom v prihodnost. (ur. Kunaver, J.) DZS. Ljubljana, str. 129-148.

Resnik Planinc, T., Kosten Zabret, S. 2007. Vpliv geografskega kurikuluma na kompetence učitelja geografije. Dela 27, Geografija in prostor, Oddelek za geografijo na Filozofski fakulteti ULj, Ljubljana, str.183-198.

Schallhorn, E. 2004. Erdkunde Didaktik, Praxishandbuch für die Sekundarstufe I und II. Scriptor - Geographieunterricht international: USA, England, Japan. Cornelsen. Westaway, J., Rawling,E., 2001, The rises and falls of Geography, Teaching geography, No.1.Sheffild, str. 9-11.

Geografija: Predmetni katalog-Učni načrt, Gimnazija (210 urni program) (www.mszs.si/slo/ solstvo/ss/programi/gimnazija/geog.htlm, 24.3.2006)

Izhodišča prenove gimnazijskih programov . Medmrežje 1: http://www.mss.gov.si/fileadmin/ mss.gov.si/pagenploads/podrocje/razvoj_solstva/izhodisca_prenove_gimnazijskega_ programa.doc, 21.3.2006)

Medmrežje 2: http://fortunecity.com/campus/dana/1471/index.html (28.6.2003)

Medmrežje 3: http://www.asn-linz.ac.at/schule/gw (4.4.2007)

Medmržje 4: http://www.bmbwk.gv.at/medienpool/877/lp_hs_geographie_877.pdf(3.9.2006)

Medmrežje 5: http://www.bmbwk.gv.at/medienpool/877/lp_hs_geographie_877.pdf (25.7.2006)

Nacionalni izobraževalni standard .2005. Medmrežje 6: http:www.mzos.hr. (11.11. 2007)

Program osnovnošolskega izobraževanja, Učni načrt Geografija, predmetna kurikularna komisija za geografijo, ZRSŠ. 2001. 
The National Curriculum attainment targets, stage $1 \& 2 \& 3$, Medmrežje 7: http://www. ncaction.org.uk/subjects/geog/targets.htm 12.1.2008

Učni načrt:program osnovnošolskega izobraževanja. Geografija. 2001.Predmetna kurikularna komisija za geografijo. ZRSŠ.

\title{
DEVELOPMENT OF GEOGRAPHICAL CURRICULA AND THE EDUCATIONAL POTENTIAL OF GEOGRAPHY AT THE BEGINNING OF $2 I^{\text {st }}$ CENTURY
}

\begin{abstract}
Summary
Permanent monitoring, upgrading and development of curriculum remain an important part of the school system, because education issues arise from social needs and therefore have to respond to the goal changes in the modern society, in which knowledge and its effects play an important role. The curriculum has to emphasize the development of the capabilities that lead to permanent learning abilities.

For successful implementation of intensive changes into national and subject curricula, expertly skilled, professionally sovereign and confident teachers are of the great importance.

In modern European geography curricula geography is defined as a school subject that educates interdisciplinarily when introducing natural and social contents. The comparison of the geographical curricula of the selected countries shows that England, Austria, Croatia and Slovenia have included into them both the regional and the spatial paradigms as the starting-point of the geographical teaching. English and Austrian primary school (and partly secondary school) geography curricula give priority to selected geographical topics and man - nature relation teaching. Croatian and Slovenian curricula have adopted a different approach. They are still the most comparable, as well as in regional content structure (selection of local, national and global regions) as in the proposed pupils' activities.

In the future it is expected that space - its location and organization and man - environment interaction will remain the core postulates of geographical education, because with the encouragement of spatial learning they evoke the development of participatory and proactive learning as the important elements of the permanent and towards constant development orientated education. Geography education can contribute significantly to learning (knowledge), understanding and respecting (evaluation) one's own homeland and national space and their co-dependent connection with the world. Geographical education can substantially collaborate in teaching the importance of learning the values, behaviour and lifestyles required for a sustainable future. Bringing global problems of the world up to date we can educate pupils on awareness of their own rights and also of their responsibility for the future. All pupils need to be given a chance to develop skills for social and political participation on different levels of decision-making and stimulate empathy for common problem solving, solidarity, searching for balance between individuality and community, between man and nature.
\end{abstract}

